\title{
Numerical analysis of deformation and mechanical properties of double corrugated pipe
}

\author{
Peng Zhou', a, Wei Fan², b, Zhihong Wang ${ }^{3, ~ c}$, Shui Wan ${ }^{1, d}$ \\ ${ }^{1}$ School of Transportation, Southeast University, Nanjing , China; \\ ${ }^{2}$ China Communications Construction Second Highway Consultants Co.Itd, Wuhan, China; \\ ${ }^{3}$ Hengshui Yitong Pipe Industry Co.Ltd, Hengshui ,China; \\ a1533895177@qq.com, b10507254@qq.com, ‘361158663@qq.com, dlanyu421@163.com
}

\begin{abstract}
Keywords:bellows; simulation; deformation; stress
Abstract. With double hole Steel corrugated pipe as the background, this paper adopted finite element analysis software ANSYS to make numerical simulation of the interaction between the pipe and the soil. At the same time, the field experiment was carried out. Comparing the results of numerical simulation with field tests, and find that the relative error of the result is little. Therefore, the rationality of numerical simulation results is proved. The deformation and stress characteristics of double bellows with different filling heights were studied by numerical simulation.
\end{abstract}

\section{Introduction}

Corrugated steel pipe culvert is a kind of culvert form that is made of corrugated shape in the form of cross section. It is a typical flexible structure of thin shell, and the corrugation makes it have excellent mechanical properties (axial and radial load bearing) and compensation for lateral displacement. It can give full play to the advantages of high strength and deformation of steel. At present, our country has carried out the research technology in the road steel corrugated pipe. In view of the rapid development of highway construction, the single-aperture corrugated steel structure cannot meet the needs of highway construction completely and porous steel structure can adapt to the project construction. In this study, the deformation and stress characteristics of double bellows with different filling height were analyzed by means of numerical simulation and field experiment. It provides a satisfied technical support for the application of multi-span corrugated pipes structure in China.

\section{The Research Methods}

Constitutive Relation.The elastoplastic model is used for the double bellows culvert, subgrade soil and backfill soil. The yield criterion of the metal plastic problem is the Von Mises criterion, and the Drucker-Prager (DP) criterion is used to analyze the backfill soil and foundation soil. The fourth strength theory is used as the criterion.

Finite Element Modeling. Finite element software ANSYS was used for modeling and analysis. The model is simplified to a circular cross section with a diameter of $6 \mathrm{~m}$. The corrugated form is $400 \mathrm{~mm} \times 150 \mathrm{~mm}$ that the wave distance is $400 \mathrm{~mm}$ and the wave height is $150 \mathrm{~mm}$. The thickness is $6.5 \mathrm{~mm}$. Symmetrical loading is applied with symmetrical modeling method. Choosing the right boundary as the symmetry plane. The thickness is $6.5 \mathrm{~mm}$, and the left margin of the corrugated pipe is $9 \mathrm{~m}$ and $0.75 \mathrm{~m}$ from the right side, i.e. $1.5 \mathrm{~m}$ between the two tubes. Four basic wavelengths are selected on the axis. The height of the foundation is $9 \mathrm{~m}$ and the highest filling is 8 meters. The boundary conditions of the soil are assumed to be a chain bar bearing only the $\mathrm{x}$ direction of the left boundary and the right boundary is symmetric. The ground surface is assumed to be the fixed end boundary condition. The function of connecting bolt is ignored. The soil body and the pipe culvert structure are connected through the joint. Axial deformation and stress are not considered. The structural finite element model is shown in figure 1. The parameters of soil and bellows are shown in table 1 . 
According to the actual backfill condition of the project, the construction is divided into 5 working conditions from the start of the filling to the final completion.

a) The filling height of both sides is $1.5 \mathrm{~m}$;

b) The filling height of both sides is $3 \mathrm{~m}$;

c) The filling height of both sides is $4.5 \mathrm{~m}$;

d) Filling the soil to the top of the pipe and the total filling height is $6 \mathrm{~m}$;

e) Completion of the filling and the final filling height to the top of the pipes is $2 \mathrm{~m}$, and the total filling height is $8 \mathrm{~m}$ from the foundation.

Deactivation elements are used to simulate the construction stage. It is assumed that the deformation and force of the left and right tubes are the same. The stress and deformation of the number 1,2,3, 4, 5 and 7 points on the left tube are selected to reflect the stress and shape changes of the structure. The specific location of the test points is shown in figure 2 below.

TABLE 1 Material parameters of the model

\begin{tabular}{|l|l|l|l|}
\hline Parameters & The steel plate & Backfill soil & Foundation \\
\hline $\begin{array}{l}\text { Modulus of } \\
\text { elasticity } \\
(\text { MPa })\end{array}$ & $2.1 \mathrm{E}+5$ & 60 & 200 \\
\hline $\begin{array}{l}\text { Poisson's } \\
\text { ratio }\end{array}$ & 0.3 & 0.3 & 0.25 \\
\hline $\left.\begin{array}{c}\text { density } \\
(\mathbf{k g} / \mathbf{m}-\end{array}\right)$ & $7.85 \mathrm{E}+3$ & $1.8 \mathrm{E}+3$ & $2.2 \mathrm{E}+3$ \\
\hline $\begin{array}{l}\text { Cohesive } \\
\text { force }\end{array}$ & - & 28 & 44 \\
\hline $\begin{array}{l}\text { Angle of } \\
\text { internal }\end{array}$ & - & 21 & 25 \\
\hline
\end{tabular}

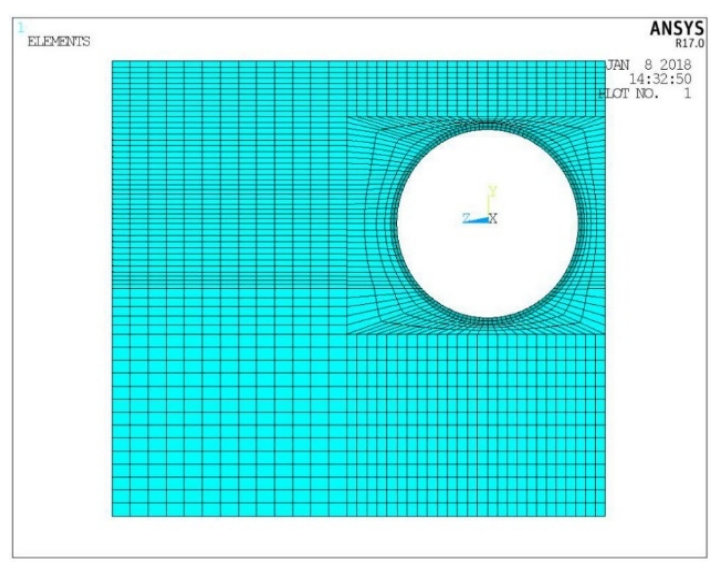

Fig 1. Figure of the finite element model

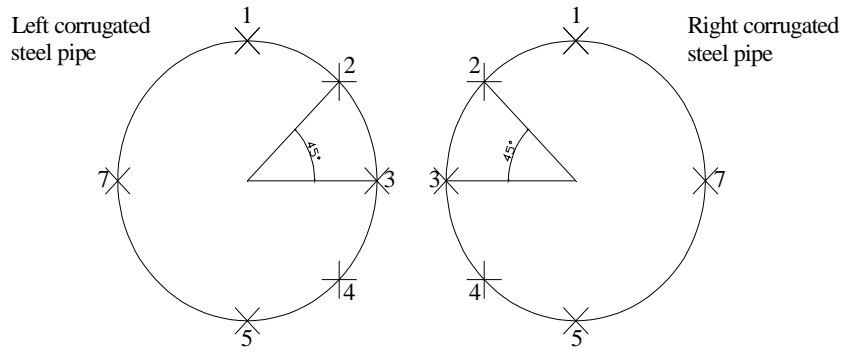

Fig 2. Figure of layout of test points

\section{Analysis of Finite Element Simulation Results}

Deformation Analysis. The results of vertical and horizontal deformation of each test point on the left pipe in each construction stage through model analysis are shown in table2, table3 figure3.Vertical deformation up is "+", downward is "-"and horizontal deformation to the left is "+", to the right is "-". Maintaining the Integrity of the Specifications.

TABLE 2 The vertical deformation results of each measuring point in the left pipe $(\mathrm{mm})$

\begin{tabular}{|l|l|l|l|l|l|l|}
\hline $\begin{array}{l}\text { depth of } \\
\text { filling(m) }\end{array}$ & $\begin{array}{l}\text { Test } \\
\text { point1 }\end{array}$ & $\begin{array}{l}\text { Test } \\
\text { point2 }\end{array}$ & $\begin{array}{l}\text { Test } \\
\text { point3 }\end{array}$ & $\begin{array}{l}\text { Test } \\
\text { point4 }\end{array}$ & $\begin{array}{l}\text { Test } \\
\text { point5 }\end{array}$ & $\begin{array}{l}\text { Test } \\
\text { point7 }\end{array}$ \\
\hline 1.5 & 2.96 & 2.98 & 2.81 & 1.58 & 0.38 & 2.01 \\
\hline 3 & 4.98 & 4.76 & 3.87 & 2.34 & 0.49 & 3.19 \\
\hline 4.5 & 6.88 & 6.58 & 4.96 & 3.03 & 0.73 & 4.47 \\
\hline 6 & 8.43 & 7.96 & 6.21 & 3.47 & 0.96 & 5.81 \\
\hline 8 & 4.19 & 2.87 & 2.98 & 0.87 & 0.17 & 2.32 \\
\hline
\end{tabular}

TABLE 3 The horizontal deformation results of each measuring point in the left pipe $(\mathrm{mm})$

\begin{tabular}{|l|l|l|l|l|l|l|}
\hline $\begin{array}{l}\text { depth of } \\
\text { filling( } \\
\text { m) }\end{array}$ & $\begin{array}{l}\text { Test } \\
\text { point1 }\end{array}$ & $\begin{array}{l}\text { Test } \\
\text { point2 }\end{array}$ & $\begin{array}{l}\text { Test } \\
\text { point3 }\end{array}$ & $\begin{array}{l}\text { Test } \\
\text { point4 }\end{array}$ & $\begin{array}{l}\text { Test } \\
\text { point5 }\end{array}$ & $\begin{array}{l}\text { Test } \\
\text { point7 }\end{array}$ \\
\hline 1.5 & -0.28 & 0.13 & -0.03 & -0.33 & -0.40 & -1.69 \\
\hline 3 & -0.47 & 0.17 & -0.07 & -0.42 & -0.51 & -2.01 \\
\hline 4.5 & -0.69 & 0.21 & -0.11 & -0.54 & -0.61 & -2.36 \\
\hline 6 & -0.85 & 0.24 & -0.14 & -0.65 & -0.72 & -2.78 \\
\hline 8 & -0.49 & 0.16 & -0.04 & -0.21 & -0.39 & -1.34 \\
\hline
\end{tabular}




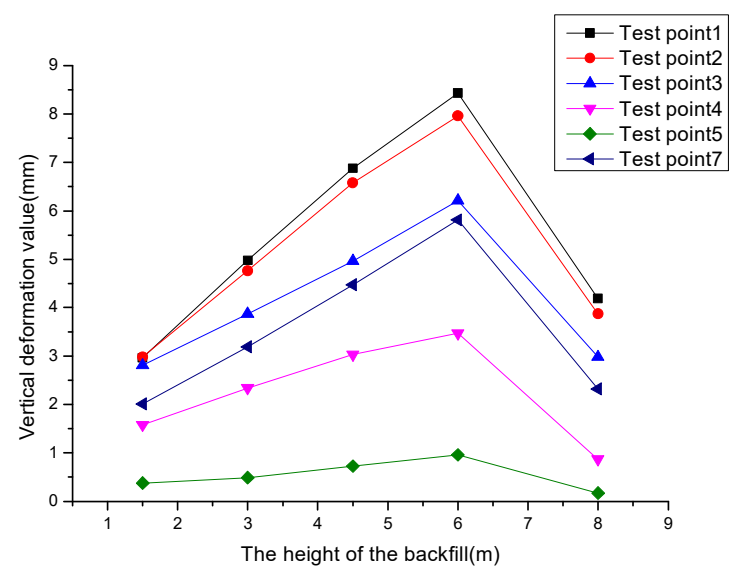

(a)

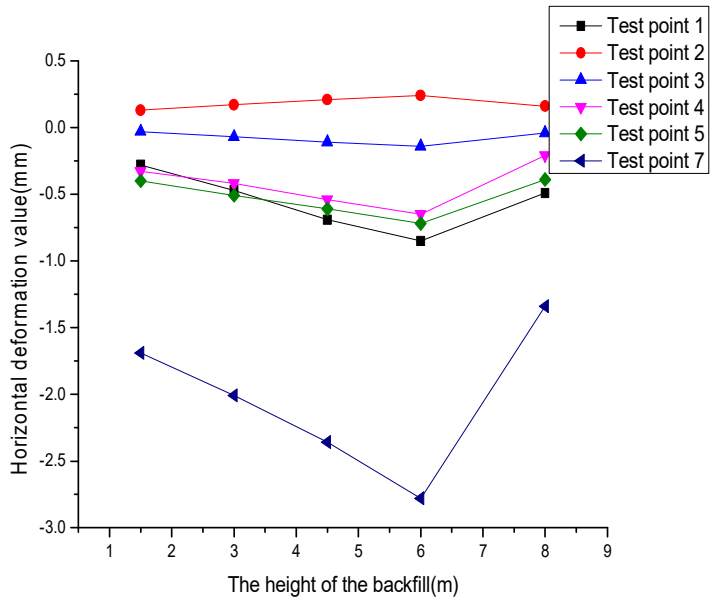

(b)

Fig 3. Vertical(a) and horizontal(b) deformation of each test point varies with the backfill height

Figure 3 shows that before the backfill reaches the top of the pipe all the test points of the bellows are rising in the vertical direction due to the role of earth pressure on both sides of the extrusion. The deformation value of test point 1 is the largest. In the vertical direction, the relative distance between test point 1 and the test point 5 becomes larger and in the horizontal direction the relative distance between test point 3 and the test point 7 becomes smaller. Therefore, the bellows will become a convex shape. This phenomenon is most obvious when the filling reaches the top of the pipe. When the filling is on the top of the pipe, the convex shape of the corrugated pipe is slowed down due to the vertical action of the load on the top soil.

Tangential Stress Analysis. The tangential stress of the wave crest and trough in the steel bellows on the left through model analysis is shown in table4, table 5 and figure4. The tensile stress of tangential stress is "+" and compressive stress is "-".

TABLE 4 The results of the trough tangential stress in the construction stage of each measuring point on the left pipe $(\mathrm{MPa})$

\begin{tabular}{|l|l|l|l|l|l|l|}
\hline $\begin{array}{l}\text { depth of } \\
\text { filling(m } \\
\mathbf{m}\end{array}$ & $\begin{array}{l}\text { Test } \\
\text { point1 }\end{array}$ & $\begin{array}{l}\text { Test } \\
\text { point2 }\end{array}$ & $\begin{array}{l}\text { Test } \\
\text { point3 }\end{array}$ & $\begin{array}{l}\text { Test } \\
\text { point4 }\end{array}$ & $\begin{array}{l}\text { Test } \\
\text { point5 }\end{array}$ & $\begin{array}{l}\text { Test } \\
\text { point } \\
7\end{array}$ \\
\hline 1.5 & -5.13 & 1.84 & 5.64 & 1.46 & -3.91 & 5.61 \\
\hline 3 & -6.69 & 2.96 & 7.01 & 2.96 & -5.25 & 7.04 \\
\hline 4.5 & -9.04 & 3.74 & 8.47 & 4.12 & -8.21 & 9.62 \\
\hline 6 & -11.76 & 5.87 & 10.04 & 5.98 & -10.92 & 12.75 \\
\hline 8 & -3.78 & 2.55 & 3.10 & 2.35 & -2.86 & 5.33 \\
\hline
\end{tabular}

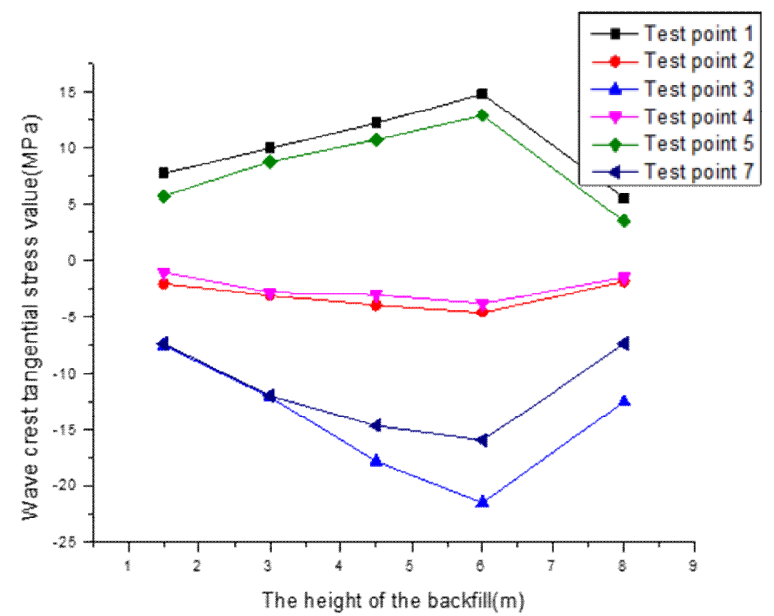

(a)
TABLE 5 The results of the wave crest tangential stress in the construction stage of each measuring point on the left pipe( $\mathrm{MPa}$ )

\begin{tabular}{|l|l|l|l|l|l|l|}
\hline $\begin{array}{l}\text { depth of } \\
\text { filling(m) }\end{array}$ & $\begin{array}{l}\text { Test } \\
\text { point1 }\end{array}$ & $\begin{array}{l}\text { Test } \\
\text { point2 }\end{array}$ & $\begin{array}{l}\text { Test } \\
\text { point3 }\end{array}$ & $\begin{array}{l}\text { Test } \\
\text { point4 }\end{array}$ & $\begin{array}{l}\text { Test } \\
\text { point5 }\end{array}$ & $\begin{array}{l}\text { Test } \\
\text { point7 }\end{array}$ \\
\hline 1.5 & 7.79 & -2.01 & -7.52 & -1.01 & 5.78 & -7.35 \\
\hline 3 & 10.01 & -3.02 & -12.01 & -2.76 & 8.82 & -11.91 \\
\hline 4.5 & 12.23 & -3.87 & -17.79 & -2.96 & 10.76 & -14.62 \\
\hline 6 & 14.88 & -4.54 & -21.45 & -3.74 & 12.91 & -15.91 \\
\hline 8 & 5.60 & -1.81 & -12.44 & -1.45 & 3.49 & -7.32 \\
\hline
\end{tabular}

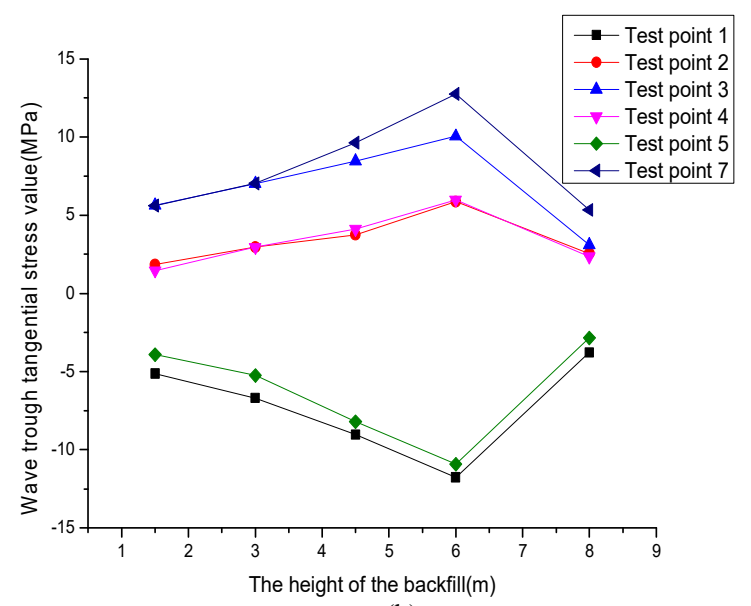

(b)

Fig 4. Figure of the wave crest(a) and though(b) tangential stress of each test point varies with the backfill height 
We can conclude that the change of tangential stress of each test point in the wave crest and trough positions is very limited before the backfill reaches the top of the pipe from figure 5 and figure 6 . With the increase of filling height, the tangential stress is increasing. At the wave crest of the pipe, near the top and bottom of the tube (test points 1 and 5), the position of the tube is tensile. At the side of the pipe (test point 2, 3, 4 and 7) are compressed. While at the wave trough of the pipe, on the contrary, near the top and bottom of the tube (test points 1 and 5), the position of the tube is compressed. At the side of the pipe (test point 2, 3, 4 and 7) are tensile. When the filling is higher than the top of the pipe, the stress of both the pressure and the tension of the wave crest and trough are gradually reduced.

\section{Numerical Simulation Compared with Test Results}

We also carried out field experiments on the site, which adopted Q235 steel corrugated pipe and adopted the construction method of site installation. The fasteners of split-piece assembly pipes adopt standard fasteners in national standard. Their strength and specifications meet the mechanical requirements and not lower than the requirements of pipe strength. The gasket matches the fastener. Both bolts and nuts are treated with hot dip galvanization. The design life of steel bellows is 100 years. The sealing material is made of rubber sealing ring or square asbestos packing strip with good square durability. The upper and upper layers of the foundation are graded with gravel, and the lower layer is equipped with good coarse sand. The design waveform adopts double tube $400 \mathrm{x} 150 \mathrm{~mm}$ (wavelength $*$ wave height). The space of double pipe is $1.5 \mathrm{~m}$. The plate thickness is $6.5 \mathrm{~mm}$ and the top filling height of pipe is $2 \mathrm{~m}$. The test tube culvert layout and field conditions are shown in figure6. The layout of the measurement points is still shown in figure 2 .

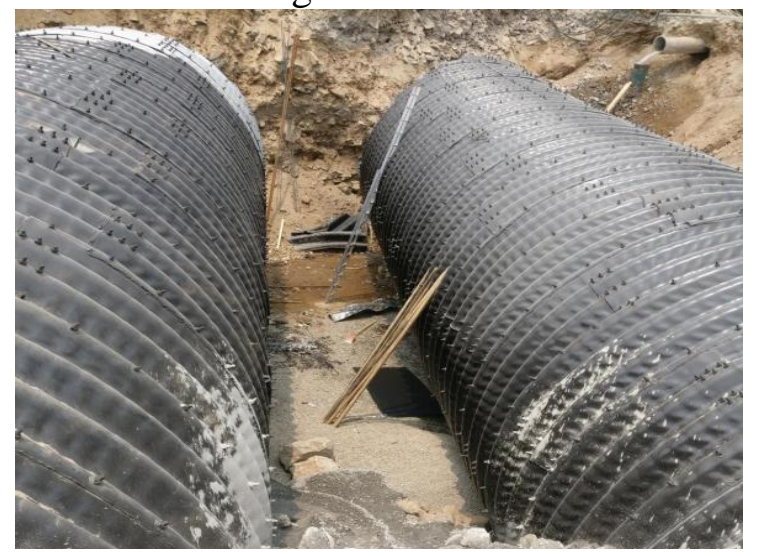

Fig 5. Figure of the layout of the bellows on the site

The strain test element selects the intelligent string digital strain gauge and the earth pressure test element chooses the intelligent string digital earth pressure box. The Total station is used to obtain the coordinates of each measuring point, then the displacement of each measuring point is obtained. There are also five calculation conditions in the filling process just like the simulation. In the process of backfilling, in order to prevent the height asymmetry of the two sides of the soil and the structure is subjected to a large deformation, the soil layer of both sides of the pipe are filled with the same high. Limited to space, we only choose part of experimental results to compare with the calculated results.

Comparison of Deformation Results. We chose the measurement point 1 to compare the changes under different filling height, and the comparison results are shown in figure 7.

Figure 7 shows that the trend of the deformation of the finite element calculation results and the field test results are the same. However, compared with the finite element calculation results, the field test results have large fluctuation and poor overall regularity.

Comparison of the Tangential Stress. We chose the measurement point 5 of the wave trough to compare the changes under different filling height. The comparison results are shown in figure 8 . 


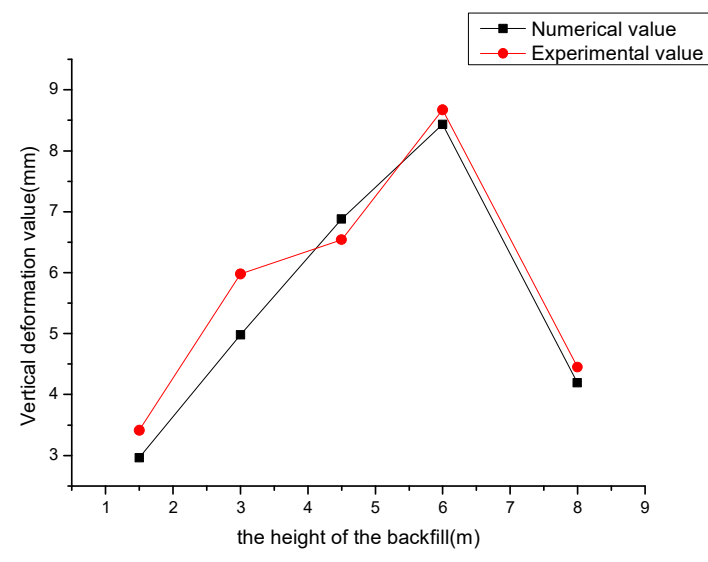

Fig 6. vertical deformation of simulation of test point 1 compared with the field experiment

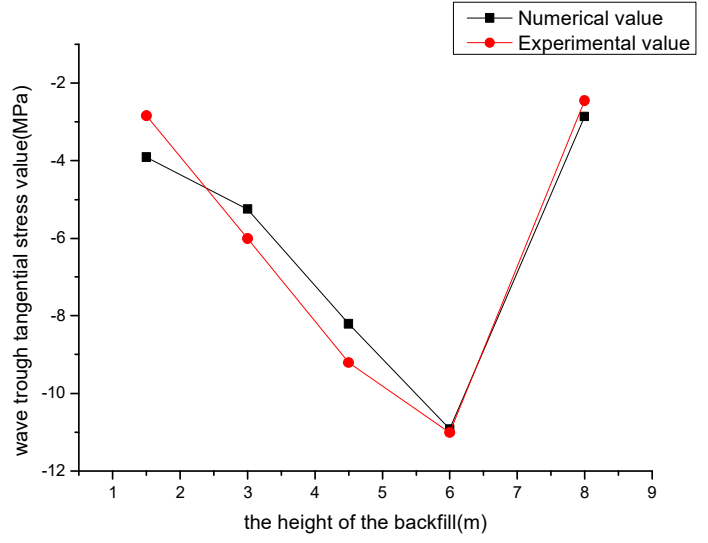

Fig 7. Figure of the wave trough tangential stress of simulation of test point 5 compared with the field experiment

As we can see from figure 7 and figure 8, compared with the finite element calculation results, the field test results have large fluctuation and poor overall regularity. However, the trend of the deformation and the stress of the finite element calculation results and the field test results are the same. Therefore, the rationality of numerical simulation results is proved.

\section{Conclusion}

Before the backfill reaches the top of the pipes, the bellows will become a convex shape due to the role of earth pressure on both sides of the extrusion. In the vertical direction, the relative distance between test point 1 and the test point 5 becomes larger while the relative distance between test point 3 and the test point 7 becomes smaller in the horizontal direction. When the filling height reaches $6 \mathrm{~m}$ (tube top), the convex shape of the corrugated pipe is slowed down due to the vertical action of the load on the top soil.

The tensile stress and compressive stress of the adjacent wave crests and the wave troughs are alternating, which is beneficial to give full play to the mechanical properties of steel. This makes the whole pipe culvert stress in a good state that wave troughs and crests mutual coordination to share the load.

Before the filling height reaches the pipe top $(6 \mathrm{~m})$, the soil pressure increase is not obvious. When the filling height reaches $6 \mathrm{~m}$ (tube top), radial earth pressure around the pipe is significantly increased.

\section{References}

[1]Hishanl Husseill Hafez. Soil-steel structures under shallow cover [D]. Windsor Ontalrio Canada. University of Windsor.1981

[2]Esra Bayoğlu Flener. Soil-Steel Interaction of Long-Span Box Culverts-Performance during Backfilling [J]. Journal of geotechnical and geoenvironmental engineering (C) ASCE / JUNE 2010. 823-832

[3]R. W. I. Brachman. Testing and Analysis of a Deep-Corrugated Large-Span Box Culvert prior to Burial [J]. Journal of Bridge Engineering, Vol. 17, No. 1, January 1, 2012. CASCE, ISSN 1084-0702/2012/1. 81-88

[4]Hesham Mohammed. Improving the Response of Soil-Metal Structures during Construction [J]. Journal of Bridge Engineering (ASCE). 2002Y.

[5]Zhang meng dong. Dynamic and stability analysis of overburden corrugated steel plates [D]. Beijing. Beijing jiaotong university.2010.

[6]Jiang xue Mei. Experimental research and calculation analysis of the highway just corrugated arch culvert and pipe culvert [D]. Beijing. Beijing Jiao tong university.2005. 